\title{
The Deep-sea Demersal Fish Fauna of the Northern Gulf of Mexico
}

\author{
Shawna M. Powell and Richard L. Haedrich \\ Department of Biology, Memorial University of Newfoundland \\ St. John's, Newfoundland, A1B 5S7, Canada \\ and \\ John D. McEachran \\ Department of Wildlife Science, Texas A\&M University \\ College Station, TX 77843-2258, USA
}

\begin{abstract}
As a part of the Deep Gulf of Mexico Benthos (DGoMB) project, fishes were sampled in May and June 2000. Thirty-seven stations were occupied using a 40' semi-balloon otter trawl along transects which ran from shallow to deep water and from northern Florida to off southern Texas. A total of 1065 individuals in 119 demersal fish species were taken. Cluster analyses showed the fish fauna is zoned with depth. Assemblages were identified on the shelf (188-216 m), upper slope (315-785 m), mid-slope (686-1 $369 \mathrm{~m})$, and in a deep zone (1533-3 $075 \mathrm{~m})$. The most abundant species found on the shelf was the small caproid Antigonia capros. On the upper slope Caelorinchus caribbaeus and Steindachneria argentea, from Macrouridae and Steindachneriidae respectively, were dominant. On the mid-slope the fauna is dominated by Macrouridae: Nezumia cyrano and Coryphaenoides zaniophorus. The deep zone is dominated by Ophidiidae: Dicrolene kanazawai and Acanthonus armatus. Species richness is highest on the upper slope (48 species) and decreases with depth; the deep zone has 32 species. Abundance, too, is greatest on the upper slope, especially in the Mississippi Trough and DeSoto Canyon, and declines greatly with depth. Data on fishes support the DGoMB hypothesis relating to depth zonation, refute the hypothesis relating to eastwest abundance, but, because of limited samples, are inconclusive regarding fauna in and out of basins. There do not appear to be species of commercial interest in the deep demersal fish fauna.
\end{abstract}

Keywords: assemblages, continental slope, deep-sea fauna, zonation, demersal fish, diversity

\section{Introduction}

The Deep Gulf of Mexico Benthos (DGoMB) project is an ongoing study to gain a better understanding of the deep-sea areas that will be potentially impacted by current and future exploration and exploitation of fossil fuel reserves. The deep waters which are of concern range across the slope and rise of the Northern Gulf in depths from 200 to $3000 \mathrm{~m}$, with sampling focussed on areas most likely to be targeted for exploitation. However, in order to understand the biological communities in the region, areas outside the potential target sites have also been sampled. The study will describe the present condition and distribution patterns in benthic and benthopelagic communities, and will determine the biological, physical, and environmental processes that influence their structure and function. In addition to their significance in the local situation, the results of the DGoMB study will provide useful material to compare and contrast the situation in the Gulf of Mexico with that of similar ocean basins elsewhere.

The deep-sea fauna of the Gulf of Mexico is not well known. Regular biological surveys did not begin until 1950, when the U.S. Fish and Wildlife Service began exploring fishing grounds (McEachran and Fechhelm, 1998). Pequegnat et al. (1990) conducted one of the few general deep-sea biological studies of the Gulf, and prior to this the true complexity of the region was not known. Among other things, that study identified three distinct physical environments in the Gulf with respect to temperature and salinity. A shallow zone occurred at a depth of $300 \mathrm{~m}$ to $600 \mathrm{~m}$, an intermediate zone occurred between 600 and 1000 $1200 \mathrm{~m}$, and a deep zone ran from this depth down to the abyssal plain.

The Gulf of Mexico has some of the most complex bathymetry in the world, with more than 90 basins 
and 7 submarine canyons (including the Mississippi Trough) in the northwestern part (Rowe and Kennicutt, 2000). Along the north, south, and east coasts of the Gulf the continental shelf is broad, ranging up to a width of $170 \mathrm{~km}$, but along the western portion it is much narrower, extending out to less than $13 \mathrm{~km}$ in some places (Salvador, 1991). The DeSoto Canyon, an erosional valley, cuts through the northeastern continental shelf. East of this, the bottom is dominated by carbonate sediment, and drops steeply to the deep ocean across the Florida Escarpment (McEachran and Fechhelm, 1998). To the west the continental slope is much less steep and is covered with terrigenous sediment. The Sigsbee Abyssal Plain has seamounts formed from upward movement of salt through the sediments (Rowe and Kennicutt, 2000). Salt diapirs have altered the sedimentation pattern in the Gulf, and may be responsible for much of the very complex topography observed on the slope there.

Comprehensive ecological studies are needed specifically for slope and rise regions in the northern Gulf of Mexico to identify factors that may influence the fauna, including faunal groups of potential commercial importance such as fishes. This is important because the region is rich in fossil fuel, and exploratory wells have been drilled there in water as deep as 2292 m (Salvador, 1991). Exploitation will occur in deep water if oil fields with commercial potential are found, so studies of the deep benthic ecosystem are needed in advance to investigate the likelihood of any significant and lasting ecological impacts.

Studies of deep demersal fish communities have been conducted worldwide, mainly concentrating on the shelf and upper slope. Environmental and biological differences between shelf and slope habitats are relatively large, and their fish faunas tend to be quite different (Bergstad et al., 1999). On the slope, fish species are generally found distributed within discrete vertical ranges (Merrett and Haedrich, 1997), and there is a zonation of entire fish assemblages with depth (e.g. Farina et al., 1997; Fujita et al., 1995; Merrett et al., 1991; Bianchi, 1992; Jacob et al., 1998). Fujita et al. (1995) concluded that the environmental variable causing faunal change with depth is difficult to specify. Other investigators found that the distributions of fish assemblages were related to environmental gradients including light level, oxygen content, pressure, and sediment properties (Cartes and Sarda, 1993; Gomes et al., 1992; Moranta et al., 1998; Jacob et al., 1998). All these factors vary with depth and furthermore may affect fish assemblages in different combinations that are not yet known (Connell and Lincoln-Smith, 1999). Temperature and salinity are also thought to play an important role in determining the zonation of faunal assemblages (Fujita et al., 1995; Jacob et al., 1998). Haedrich and Krefft (1978), reported fish assemblages changed in relation to a combination of depth and temperature. Stefanescu et al., (1993) determined there is high environmental stability in the Catalan Sea below a depth of 150 to $200 \mathrm{~m}$ for both temperature and salinity, but even so the deep-sea fauna show a pattern of zonation. So, beyond the physical factors, biological factors may also be important for influencing the distribution of different faunal assemblages.

Biological factors that may influence faunal assemblage zones include resource availability, predator-prey relationships, and interspecific competition (Moranta et al., 1998; Anderson et al., 1985). An important food resource for demersal fish on the upper slope is the pelagic fauna (Gordon et al., 1995; Fujita et al., 1995). McClatchie et al. (1997) discovered that the mesopelagic fauna in the area might determine the size and composition of demersal fish assemblages. Below a depth of $1200 \mathrm{~m}$ in the Catalan Sea, there is a large reduction in the trophic resources that are available for use (Stefanescu et al., 1993), and this is reflected in the biomass, which also changes at this depth. Available resources are less, due to a decrease in the mean weight of the decapod crustaceans that figure in fish diets (Cartes and Sarda, 1993). Interspecific competition can be important because demersal fish species are generally higher in the food web, and competitive interactions between groups of species may be stronger at higher trophic levels (Cartes and Sarda, 1993).

The Gulf of Mexico is often described as a Mediterranean-type sea (Pequegnat et al., 1990), and it is worth making some comparisons. In the Catalan Sea (Western Mediterranean) a declining trend in biomass but not abundance was found over a depth range of 1 000-2 250 m (Farina et al., 1997; Stefanescu et al., 1993). In the Algerian Basin the same trend for demersal fish species is also found below a depth of $1100 \mathrm{~m}$ (Moranta et al., 1998). Species richness declined with depth (Moranta et al., 1998; Farina et al., 1997). The Mediterranean Sea has high environmental stability in both temperature and salinity (Moranta et al., 1998; Cartes and Sarda, 1993; Stefanescu et al., 1993), which is not the case in the Gulf of Mexico. As is the case in the Gulf of 
Mexico, the upper and middle slopes are cut by several submarine canyons (Cartes and Sarda, 1993) and the topography is complex. The number of demersal species in the Mediterranean on the lower slope and deeper is much lower than the number reported for the North Atlantic. This may be due to the shallow sill in the Gibraltar Strait, which impedes the deepwater exchange and possibly the species that live there. The fauna of the Gulf of Mexico is more typical of that found in the deep-sea of the Atlantic Basin (Pequegnat et al., 1990).

The present study presents data on Northern Gulf of Mexico deep demersal fishes identified from a DGoMB research cruise on R/V Gyre that took place in May and June 2000. This paper analyzes the fish data, presents a picture of distribution patterns, and uses the data to examine some of the DGoMB's core hypotheses. These hypotheses are:

$H_{01}$ : Variation in demersal fauna is best correlated with depth

$H_{02}$ : Faunas exhibit an east-to-west gradient

$H_{03}$ : Basin faunas are different from non-basin faunas

The DGoMB cruise was designed to sample the broadest range of relevant conditions at depths from $200 \mathrm{~m}$ to over 3000 metres. The main hypothesis is that the faunal variation is correlated with depth, and this was examined primarily with data arranged in shallow-to-deep transects. To test the east-to-west gradient, samples were used from stations at similar depths from transects in the east, central, and western portions of the Northern Gulf. Basin fauna and nonbasin fauna were tested in a similar manner.

\section{Materials and Methods}

The data were obtained from bottom trawl catches made on a cruise of the R/V Gyre. Forty-three stations were sampled between 4 May and 18 June 2000, in two legs. The first leg took place between 4 May and 23 May 2000 and the second leg between 30 May and 18 June 2000 . At 6 of these stations, no trawling was conducted or the net was lost. At another 6 stations no fishes were caught, resulting in positive fish data from 31 stations. A letter and number are used to distinguish between the sites. Sites denoted with a C are on the central transect, $\mathrm{M}$ are in the Mississippi Trough, and $\mathrm{S}$ are in the DeSoto Canyon and along the Florida Escarpment. Sites with a B are in basins, and those with NB are not; $\mathrm{AC}$ is the Alaminos Canyon, $\mathrm{W}$ is the western transect, and RW is the far west transect. By sampling this far to the west, the data can be used to enforce the distinction between the fauna in the east and the west found earlier by Pequegnat et al. (1990). A chart showing station locations appears in Fig. 1; see Powell (MS 2001) and also the website: http://www.gerg.tamu.edu/GERG/ dgomb.htm.

To sample the megafauna, including fishes, $40^{\prime}$ semi-balloon otter trawls (OTSB) with 2.5-inch stretch mesh were used. The OTSB is a commercial shrimp trawl that is towed on a single warp, and is opened hydrodynamically by the spreading of two steel otter doors (Merrett and Haedrich, 1997) or by $7^{\prime} \times 14^{\prime}$ wooden doors (Rowe and Kennicutt, 2000), resulting in an effective mouth opening of $9 \mathrm{~m}$. These trawls are widely used in Atlantic deep-sea sampling, but are relatively small and without doubt undersample the fauna. At each station, CTD profiles were taken with a 12-bottle rosette cast to obtain data for routine water chemistry. Five full GOMEX sediment box cores from the bottom were sub-sampled for bacteria, meiofauna, macrofauna, geochemical and geological properties, trace metals, and trace organic contaminants.

Data were analyzed using the computer program packages MS Excel, NTSys, and MapInfo Professional. MS Excel was used to organize and store the data, NTSys was used for exploratory cluster analyses (Omori and Ikeda, 1984), and MapInfo was used to map the results. The data were first displayed in Excel spreadsheets, where they were formatted for use in other programs. Cluster analyses were used to determine relationships between stations and to establish faunal patterns (Bergstad et al., 1999; Cartes and Sarda, 1993; Bianchi, 1991). A common similarity index is the Bray-Curtis Dissimilarity index (Bergstad, 1990), and this was used in our analysis. The index ranges in value from 0 to 1 , with 0 indicating that the stations are completely similar and 1 they are completely different (Krebs, 1999). To avoid the confusing diagram that results when stations with low catches are included, only stations that had 5 or more species were used in the cluster analysis. In order to deal with the stations that were not used to produce the diagram, the similarity matrix was examined in order to determine appropriate linkages. The similarity matrix was used instead of the arbitrary choice of cut-off points in a cluster diagram to fit the stations together in a rational manner. Statistical analyses and comparative calculations, including Shannon-Weiner diversity (Krebs, 1999), were done using Excel. Data are archived with the DGoMB project office at Texas A\&M University. 


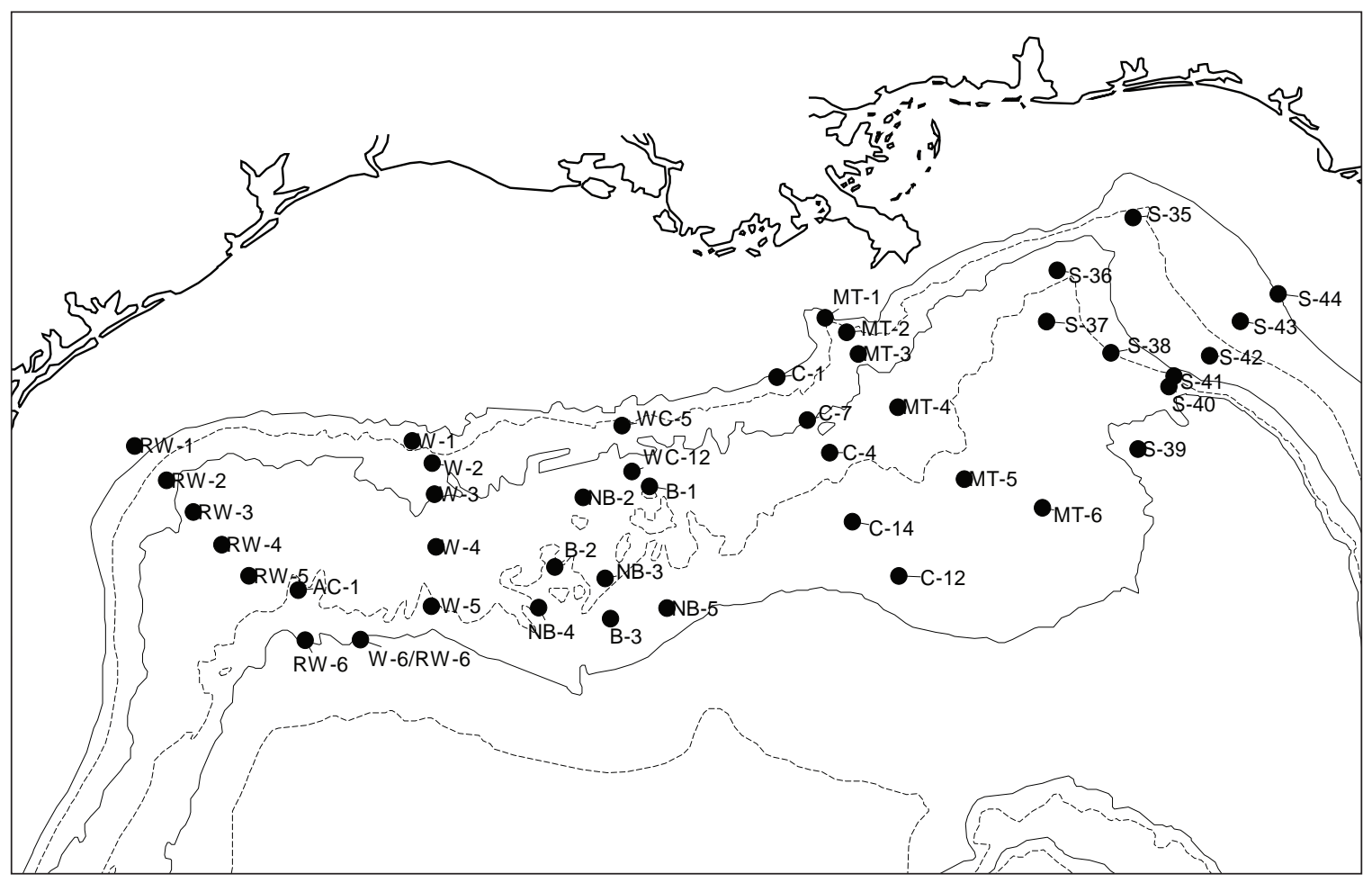

Fig. 1. DGoMB stations in the northern Gulf of Mexico, R/V Gyre May-June 2000. The depth contours are $20 \mathrm{~m}$ (solid line), $500 \mathrm{~m}$ (dashed line), $1000 \mathrm{~m}$ (solid line), $2000 \mathrm{~m}$ (dashed line), and $3000 \mathrm{~m}$ (solid line).

\section{Results}

\section{General patterns}

A total of 119 fish species comprising 1065 individuals were sampled in 31 trawl samples. A list of species and the corresponding depth zone where they are found is given in Appendix Table 1. A cluster analysis utilizing the Bray-Curtis Dissimilarity Coefficient was used to divide the stations into groups on the basis of species composition and relative abundance. The cluster diagram, based then on 19 stations, suggests that the fishes are divided by depth into four discrete assemblages (Fig. 2). A zone on the deep shelf was found between depths of $188 \mathrm{~m}$ to 216 $\mathrm{m}$, on the upper slope between $315 \mathrm{~m}$ and $785 \mathrm{~m}$, on the mid-slope between $686 \mathrm{~m}$ and $1369 \mathrm{~m}$, and in the deep waters between $1533 \mathrm{~m}$ and $3075 \mathrm{~m}$.

Sixty-six individuals from 16 species were caught in two stations on the deep shelf. The dominant species from this zone was Antigonia capros, which comprised $52 \%$ of the fishes caught there. Peristedion miniatum comprised another $15 \%$. The caproid A. capros inhabits near bottom areas between $64 \mathrm{~m}$ and $385 \mathrm{~m}$ in depth and is found in warm temperate to tropical waters (McEachran and Fechhelm, 1998). The other dominant shelf species, from the family Peristediidae, is found in shallow water up to depths of 180 meters on muddy or sandy substrate (Scott and Scott, 1988). Both of the dominant deep-shelf fishes are small (less than $300 \mathrm{~mm}$ ) and feed mainly on crustaceans.

Four hundred and fifty-six individuals belonging to 48 species were caught in 6 stations on the upper slope. The dominant species were Caelorinchus caribbaeus, Steindachneria argentea, and Yarella blackfordi, which comprised $11.6 \%, 8.3 \%$ and $7.8 \%$, respectively, of the total number of fishes caught on the upper slope. Caelorinchus caribbaeus belongs to the family Macrouridae and is generally found between depths of 200 to $750 \mathrm{~m}$ in the sub-tropical to tropical Atlantic Ocean. These fishes feed on invertebrates and fish, and reach lengths of $300 \mathrm{~mm}$ (McEachran and Fechhelm, 1998). Steindachneria argentea from the family Steindachneriidae is found on the slope in depths of up to $500 \mathrm{~m}$. This species is distributed in the Gulf of Mexico and Caribbean Sea, and reaches lengths of $277 \mathrm{~mm}$ (McEachran and Fechhelm, 1998). The diet of this fish is unknown. The third dominant species on the upper slope belongs to the family Phosichthyidae. This lightfish is also found in the tropical and subtropical Atlantic Ocean 


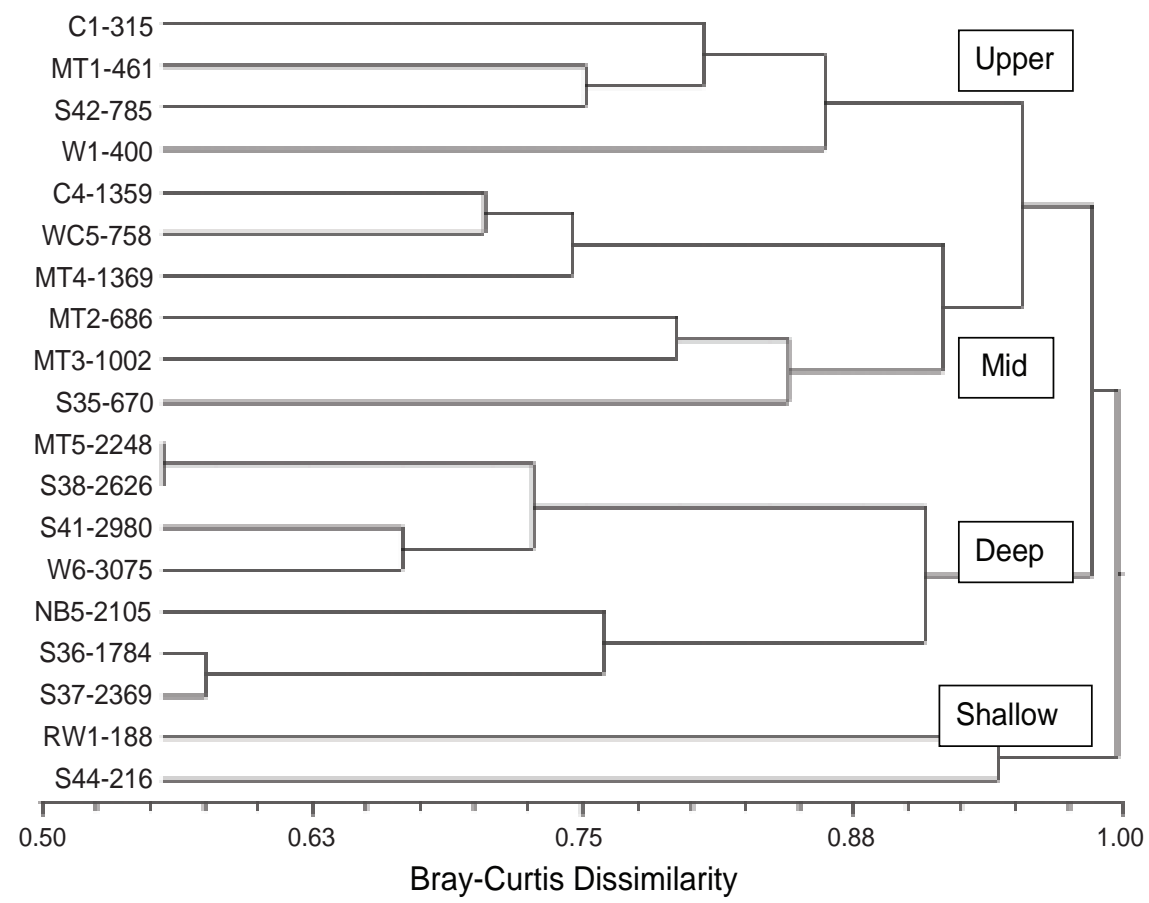

Fig. 2. Cluster analysis of DGoMB stations. Demersal fish data compared with the BrayCurtis Dissimilarity Coefficient. Labels are station designation and mean depth.

and feeds on crustaceans; it reaches a length of 322 mm (McEachran and Fechhelm, 1998).

On the middle slope 45 species and 441 individuals were caught in 8 stations. The dominant species in this zone were Nezumia cyrano consisting of $15.8 \%$ of the catch, Coryphaenoides zaniophorus consisting of $13.8 \%$, and Nezumia aequalis, which comprised $11.1 \%$. All of these species are in the family Macrouridae. Nezumia cyrano is found in depths ranging from $640 \mathrm{~m}$ to $1324 \mathrm{~m}$ and feeds on invertebrates and fish. It reaches maximum lengths of $280 \mathrm{~mm}$ (McEachran and Fechhelm, 1998). Coryphaenoides zaniophorus is found in depths ranging from $400 \mathrm{~m}$ to $2165 \mathrm{~m}$, and feeds on a wide range of organisms, including polychaetes, copepods, and echinoderms. C. zaniophorus can reach lengths of $400 \mathrm{~mm}$ (McEachran and Fechhelm, 1998). Nezumia aequalis ranges from depths of 200 meters to $1000 \mathrm{~m}$ and feeds on polychaetes, mysids, and amphipods (McEachran and Fechhelm, 1998). Its maximum size is $300 \mathrm{~mm}$.

In the deep zone 101 individuals from 32 species were caught in 15 stations. Dicrolene kanazawai was the dominant species, consisting of $11.8 \%$ of individuals. This cusk-eel from the family Ophidiidae is found from depths of $2070 \mathrm{~m}$ to $2367 \mathrm{~m}$ in the Gulf of Mexico and Caribbean Sea. Its maximum length is $254 \mathrm{~mm}$ (McEachran and Fechhelm, 1998). Bassozetus robustus comprised $9.9 \%$ of the catch $B$. robustus is found in both the western Atlantic and western Pacific Oceans at depths of less than $2000 \mathrm{~m}$ (McEachran and Fechhelm, 1998). This cusk-eel (Ophidiidae) feeds on polychaetes and crustaceans and reaches a maximum size of $360 \mathrm{~mm}$.

The upper slope had the greatest abundance of fishes, followed by the middle slope (Fig. 3). The deep zone had the fewest fishes. The geographical distribution of abundance is shown in the map in Fig. 4. The greatest numbers of fishes were found in the Mississippi Trough and DeSoto Canyon. Further west, the number of fishes decreased.

Species richness by zone is shown in Fig. 5. The greatest number of species (48) was found on the upper slope. The number of species decreases with depth, with 32 found in the deep zone. The shelf had only 16 species, but this is attributed to the small sample 
size (2 stations). The highest number of species was found in the Mississippi Trough and DeSoto Canyon (Fig. 6).

The diversity of species in each of the zones was calculated using the Shannon-Weiner index H'. The value of this so-called 'dominance diversity' depends on how the relative abundances are distributed among the different species in each assemblage (Krebs, 1999). The highest diversity was found on the upper slope

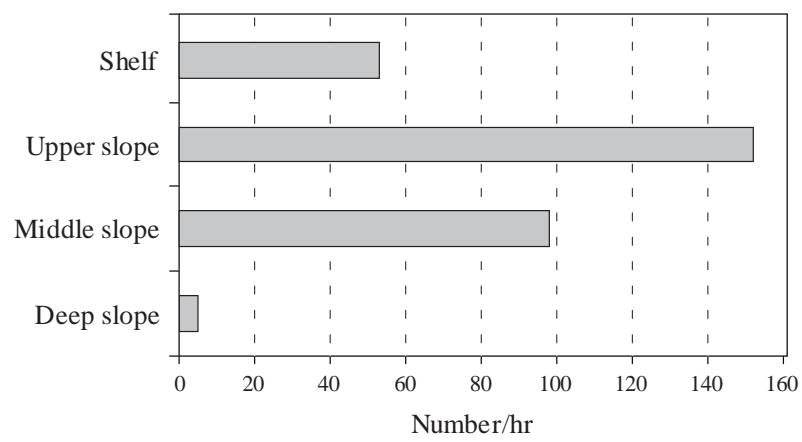

Fig. 3. Abundance (number/hr) of the fish fauna in each of the four depth zones.
(Fig. 7), the diversity on the mid-slope and deep zone were similar. The shelf had the lowest species diversity, but this may well be an artifact due to sampling as only two stations were sampled.

\section{Tests of DGoMB Hypotheses}

The fish data were used to test the hypotheses put forward for the DGoMB project. The first of these hypotheses is that variation in demersal fauna is correlated with depth. The data, based on the results

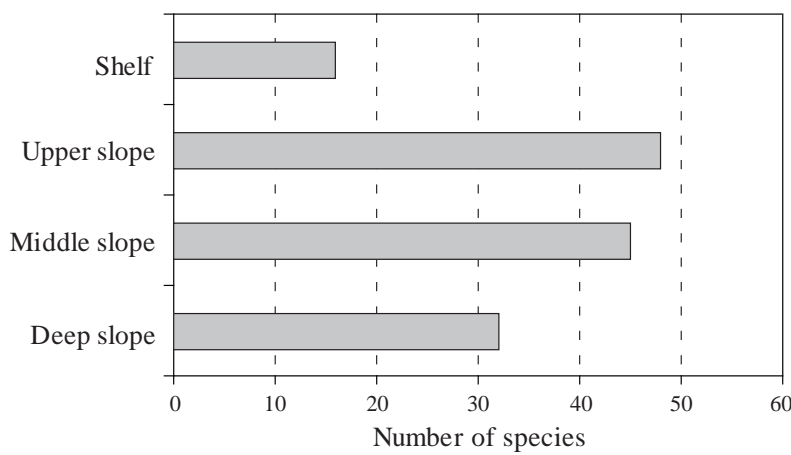

Fig. 5. Species richness of the fish fauna in each of the four depth zones.

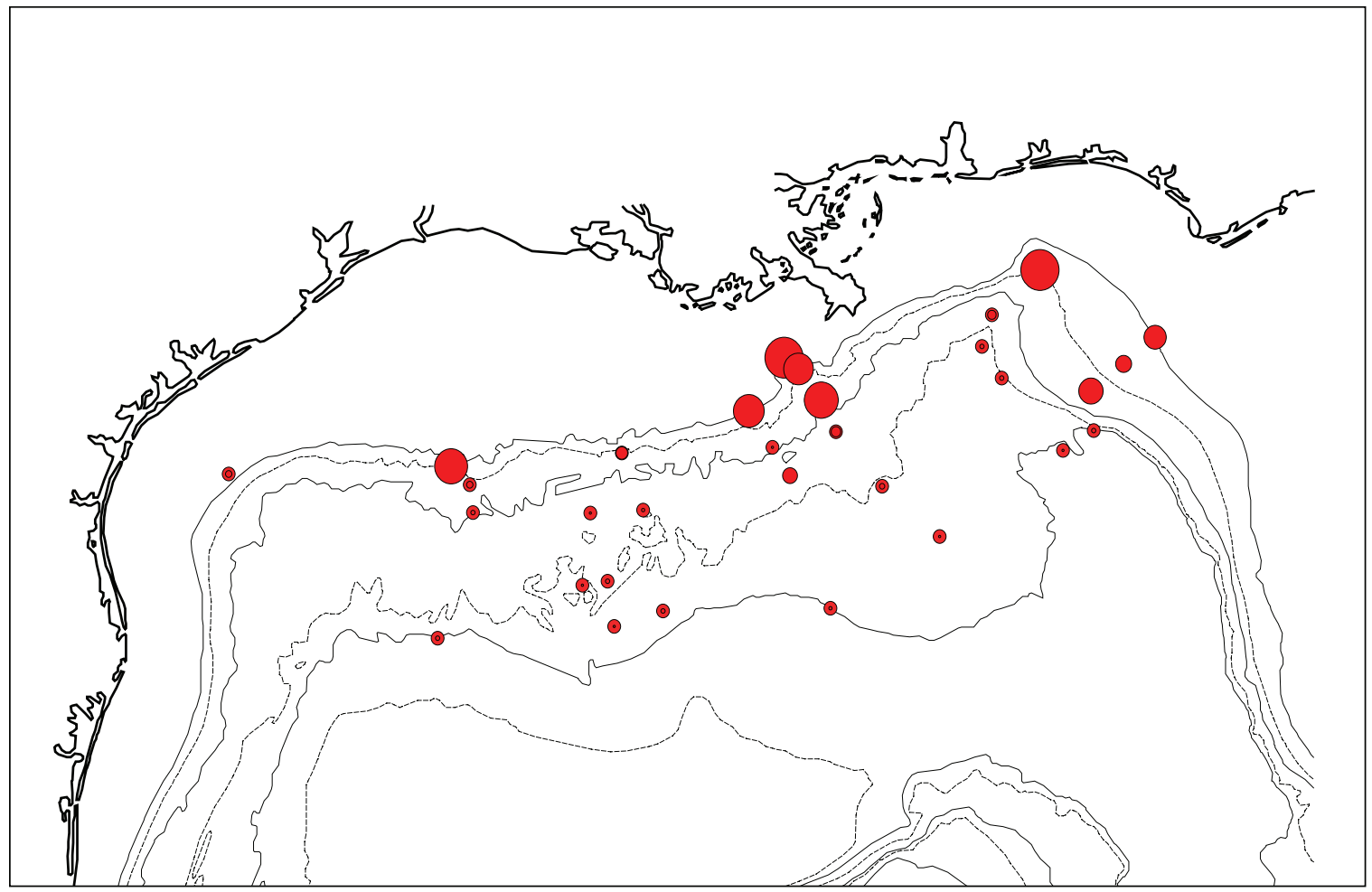

Fig. 4. The abundance of fish at each DGoMB station, scaled as the log of the number/hr. The largest dot is equivalent to a CPUE of $290 \mathrm{fish} / \mathrm{hr}$. The remaining dots are scaled appropriately. 


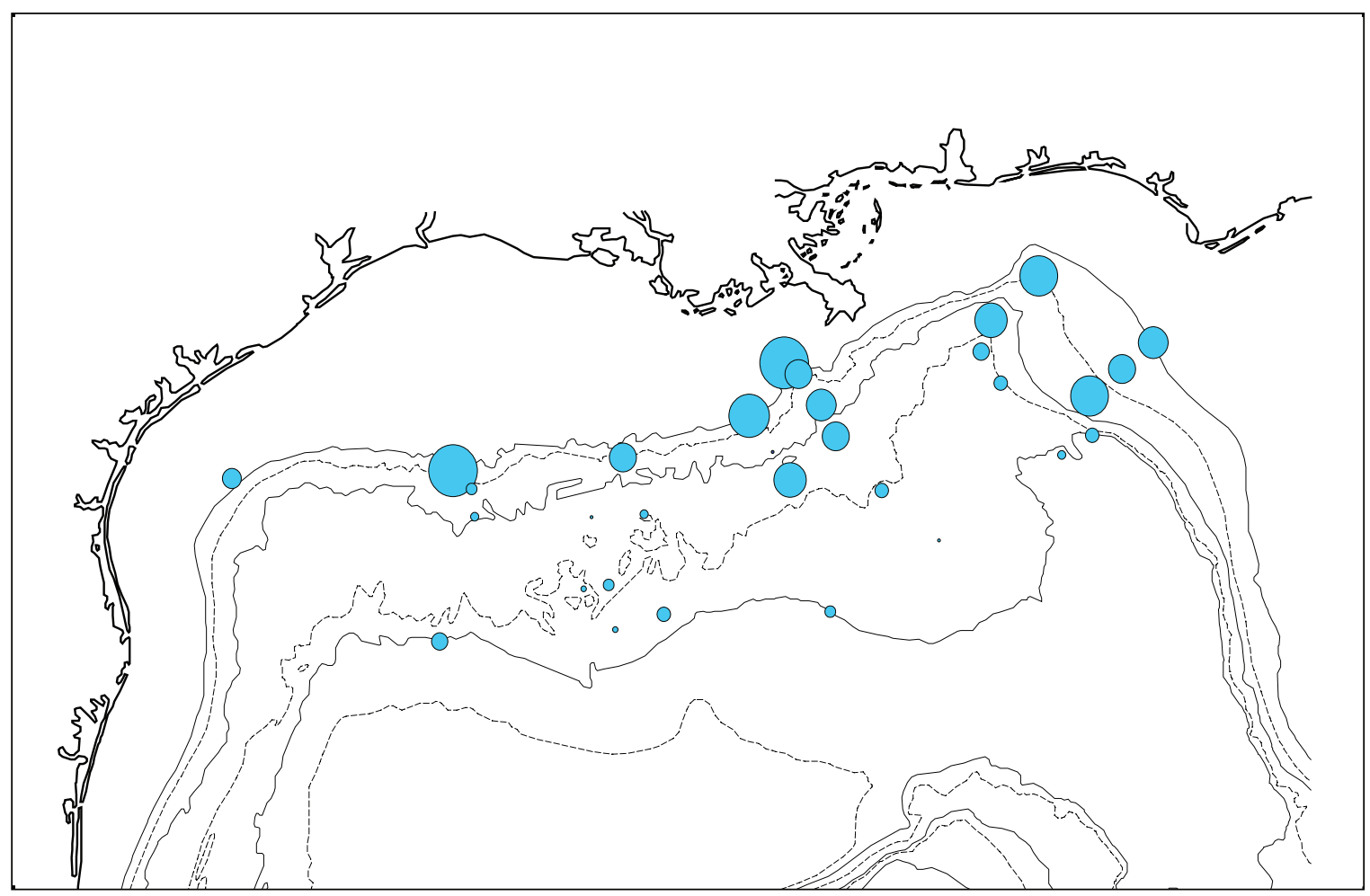

Fig. 6. Species richness of fishes at each DGoMB station, scaled directly to the number of species. The largest dot is equivalent to 18 species. The remaining dots are scaled appropriately.

from the cluster analysis, are summarized in Table 1. The highest CPUE (number/hour) is found on the upper slope, as is the greatest number of species and species diversity. The lowest CPUE is found in the deep zone. To determine how depth plays a role, the percent overlap of species between zones was calculated. There was little overlap between the assemblages, indicating that these identified zones are well defined. The lowest overlap was between the shelf and upper slope, i.e. only $3.2 \%$, however this may be

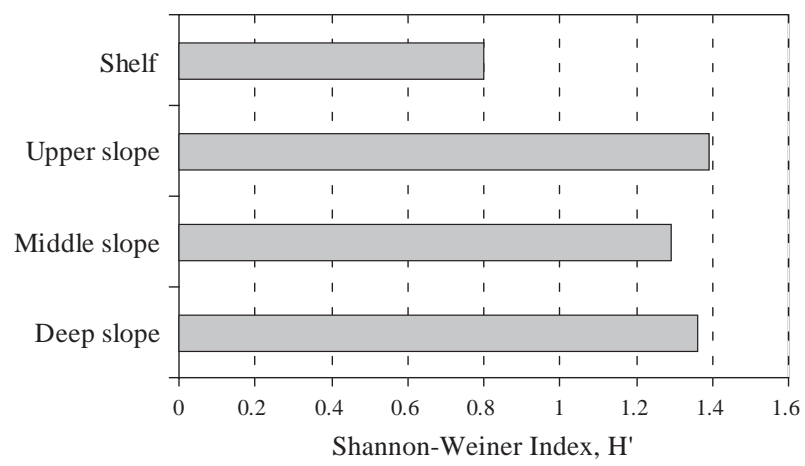

Fig. 7. Species diversity $\left(\mathrm{H}^{\prime}\right)$ of the fish fauna in each of the four depth zones. due to few shelf stations. The greatest overlap was between the upper slope and mid-slope at $16.8 \%$. These data strongly suggest that variation in the fish fauna is correlated with depth, and therefore support the hypothesis.

The second hypothesis stated that fauna exhibit an east-to-west gradient. Since the fishes are zoned with depth, comparisons were made from east-to-west first in shallow water (shelf and upper slope) and second in deep water (mid-slope and deep zone). In the first analysis of the shallow areas, the Mississippi Trough was also separated out since it is so well

TABLE 1. Faunal differences by depth between zones, from a total of 31 stations.

\begin{tabular}{lcccc}
\hline \hline Hypothesis-1 & \multicolumn{4}{c}{ Depth Zones } \\
\cline { 2 - 5 } & Shelf & Upper slope & Mid-slope & Deep \\
\hline CPUE & 52.8 & 152 & 98 & 5.2 \\
Species & 16 & 48 & 45 & 32 \\
H' Diversity & 0.80 & 1.39 & 1.29 & 1.36 \\
\% overlap & 3.2 & 16.8 & 5.9 & \\
\hline
\end{tabular}


defined and to determine if species composition was different in the trough than in other areas of the Gulf. The results of the first analysis are summarized in Table 2. The catch rate was the highest in the trough with $234 \mathrm{fish} / \mathrm{hr}$, and lowest in the western region with $65.3 \mathrm{fish} / \mathrm{hr}$. The number of species caught is highest in the west with 36 species and lowest in the central region with 15 species. Thus the highest species richness is found in the west, and the lowest is found on the central transect. Diversity $\left(\mathrm{H}^{\prime}\right)$ on the western transect is higher than diversity in the trough. The overlap between transects shows that each region is rather distinct, since these numbers are generally low. The highest degree of overlap is between the east and the trough, with an overlap of $22.8 \%$, and the lowest overlap is between the central and western transects, with an overlap of $9.9 \%$. No noticeable eastwest trend in the fish fauna could be detected, especially when the trough is included, and therefore the shallow data do not support the hypothesis.

The trough was not separated out during the examination of this hypothesis in deeper water because it cannot be readily identified at the greater depths. The deep stations found in the Mississippi Trough were combined with the central transect stations. The results of a second east/west analysis are displayed in

TABLE 2. Faunal differences from east to west at shallow depths using data from 10 stations. The last value for overlap is between east and west.

\begin{tabular}{lcccc}
\hline \hline \multirow{2}{*}{ Hypothesis-2 } & \multicolumn{4}{c}{ Shelf / Upper slope } \\
\cline { 2 - 5 } & West & Central & Trough & East \\
\hline CPUE & 65.3 & 196.0 & 234.0 & 103.0 \\
Species & 36 & 15 & 27 & 34 \\
H' Diversity & 1.28 & 0.81 & 1.14 & 1.22 \\
\% overlap & 9.9 & 13.4 & 22.8 & 16.9 \\
\hline
\end{tabular}

TABLE 3. Summary of faunal differences from east to west at deep depths using data from 15 stations.

\begin{tabular}{lccc}
\hline \hline Hypothesis-2 & \multicolumn{3}{c}{ Deep } \\
\cline { 2 - 4 } & West & Central & East \\
\hline CPUE & 3.4 & 4.0 & 8.1 \\
Species & 17 & 10 & 21 \\
H' Diversity & 1.13 & 0.94 & 1.23 \\
\% overlap & 24.1 & 30.8 & 51.1 \\
\hline
\end{tabular}

Table 3. From this analysis, the greatest CPUE was on the eastern transect and the lowest was in the west. The eastern transect also had the greatest number of species, while the lowest was found in the central region. The highest diversity was also found in the eastern Gulf. Percent overlap of the three transects shows the east and west are the most similar, with $51.1 \%$ similarity. Therefore, the east and west are more similar to each other than either one is to the closer central transect. Nonetheless, values for the fish fauna in the east tend to be higher.

The third hypothesis states that basin faunas are different from non-basin faunas. To determine the validity of this statement, stations in basins were compared to stations of similar depths that were not in basins. The results obtained from these comparisons are shown in Table 4 . The number of fish caught, the number of species and the diversity is highest in the non-basin sampling areas. The overlap between the two areas is $31.3 \%$ and the non-basin areas have higher values. However, the number of stations (6) used to test this hypothesis is very low, and therefore the results are not definitive. Further sampling to test this hypothesis is needed.

\section{Discussion}

The Northern Gulf of Mexico is characterized by four demersal fish assemblages arranged according to depth. This zonation of fauna with depth has previously been found in other studies (e.g., Cartes and Sarda, 1993; Stefanescu et al., 1993; Moranta et al., 1998; Jacob et al., 1998). Cartes and Sarda (1993) found that deep-sea decapods were zoned with depth in the Catalan Sea. Moranta et al. (1998), also found fish zonation with depth on the continental slope of the Balearic Islands in the Mediterranean. Jacob et al. (1998) found the fish fauna off the coast of New Zealand was zoned by depth as it related to change in temperature. The depth zones from the current study also correspond to the depth zones found in the North Atlantic Basin (Haedrich and Merrett, 1988).

TABLE 4. Faunal differences between basins and non-basins using six stations ( 3 basin and 3 non-basin).

\begin{tabular}{lcc}
\hline \hline Hypothesis-3 & Basin & Non-basin \\
\hline CPUE & 2.3 & 4.0 \\
Species & 6 & 8 \\
H' Diversity & 0.73 & 0.86 \\
\% overlap & 31.3 & \\
\hline
\end{tabular}


There were 16 species caught on the deep shelf, and of these $13(81.3 \%)$ were found only there. The reason for this high percentage on the shelf may be an artifact due to the few stations and small number of species caught. On the upper slope there were 48 species, with $29(60.4 \%)$ limited to this zone. On the middle slope Nezumia cyrano, Coryphaenoides zaniophorus, and $N$. aequalis were dominant. A study by Hecker (1990) on the continental slope off the southern coast of New England also found Nezumia spp. dominant on the middle slope, defined as depths between 500 and $700 \mathrm{~m}$. The most distinctive faunal zone occurs on the deep zone, with 28 of 32 (87.5\%) fish species found only there. The deep zone was dominated by species in the family Ophidiidae. Ophidiiforms are important members of demersal fish assemblages and can comprise $12 \%$ of the species found at deep depths (Merrett and Haedrich, 1997).

The abundance of fishes is greatest at depths between 315 and 785 on the upper slope. In the eastern Pacific, Bianchi (1991) found the highest biomass was along the shelf-upper slope boundary. Fujita et al. (1995), found communities on the upper slope are characterized by high abundance, but low species diversity. In the current study, high abundance was also found on the upper slope, as was high species diversity. Lowest abundance was on the deep zone. A decrease in fish abundance with depth is commonly reported from other study areas (e.g. Moranta et al., 1998; Farina et al., 1997; Fujita et al., 1995). Stefanescu (1993) found both the abundance of fishes and available trophic resources decreased with depth. Hecker (1994) found the middle-lower slope had very low megafaunal densities overall.

The greatest fish abundance was found in the Mississippi Trough and DeSoto Canyon. These channels and troughs are typical features of areas with broad continental shelves (Bergstad, 1990), as is the case on the northern, southern, and eastern parts of the Gulf of Mexico. In the Balearic basin in the Mediterranean submarine canyons on the slope are known to exert an important influence on both the environment and megafaunal communities (Moranta et al., 1998).

Species richness is highest on the upper slope with 48 species. The mid-slope has 45 species, and this decreases at deeper depths, to 32 species in the deep zone. The shelf has the lowest species richness, with only 16 species reported, although this is obviously too low. There is usually a maximum in species richness at mid-slope depths (Gage and Tyler, 1991). There is a general trend of fewer species at abyssal depths (Merrett et al., 1991), and this is the case in the current study. Species richness is greatest in the Mississippi Trough. It can be argued the trough is more likely disturbed by turbidity currents and related phenomenon, and thus the intermediate disturbance hypothesis of Dayton and Hessler (Krebs, 1994; Meffe and Carroll, 1997) could also be invoked in the region, giving a possible explanation to the high number of species in the Mississippi Trough. The high number of species in this area may be the result of the influx of nutrients from the Mississippi River, leading to higher biomass and an increase in available trophic resources. Canyons are generally productive areas and are therefore utilized by a wide range of fauna (Bergstad, 1990). Since there appears to be a higher biomass in canyon areas, there is also a greater abundance of potential food sources for demersal fish species. Although the diets of deep-sea fishes are not well known, there is a lack of obvious food selection.

The highest diversity $\left(\mathrm{H}^{\prime}\right)$ is found on the upper slope. This is in contrast to Fujita et al. (1995), who reported diversity on the upper slope off Japan to be low. The shelf has the lowest species diversity, possibly a result of limited sampling there. The mid-slope and the deep zone have similar values for species diversity, at 1.29 and 1.36 , respectively. Diversity is reported to be higher in the deep sea than in shallow areas for benthopelagic fishes (Gage and Tyler, 1991; Omori and Ikeda, 1984). The similar species diversity suggests that the uniformity of the environment increases with depth. The previous study of the Gulf by Pequegnat et al. (1990), found that species diversity in the northern Gulf decreased with increasing depth. Haedrich (1997) reported that in general the greatest fish diversity is founds in the depth range from 400 meters to 2000 meters.

The first DGoMB hypothesis states that faunal differences are correlated with depth. The cluster analysis indicated that stations were grouped together according to depth on the basis of fish species present. The faunas in the zones identified were compared to determine how much overlap there was between them (Table 1). At all levels, the overlap was small, indicating that each zone was in fact distinct. The greatest similarity, between the upper slope and midslope, was $16.8 \%$. The least difference would be expected between the deeper zones, due to an increase in environmental homogeneity with depth. 
The second DGoMB hypothesis expected there would be faunal differences along an east-to-west gradient. Due to the depth zonation of the fauna determined earlier, two comparisons were made. The first comparison in the shallow zone showed fish abundance was highest in the trough and lowest in the west (Table 2), a fact that was obvious in individual maps of abundance. The different regions all have low percentages of overlap, indicating they are distinct from one another. High abundance in the trough could be related to the high trophic resources that are available in the region (Unpub. DGoMB Data). For the second comparison using deeper areas, the trough was not separated, since it is not as distinct there (Table 3). In these deeper zones the central transect had the lowest species richness and species diversity. The fewer species in the central region as compared to the east and west may be due to the influence of the river. Maps show a high abundance of trash in this region compared to others. There may be a large amount of pollution flowing through this area, e.g. material flushed from the well-known Gulf of Mexico dead zone that could affect the composition of fish assemblages. The east and west transects were similar to each other, with an overlap of $51.1 \%$.

The final hypothesis concerned faunal differences between basins and stations at similar depths that were not in basins. There was little difference between the basin and non-basin in terms of fish fauna (Table 4). The abundance is very low in both, as well as the number of species. The percent overlap between the two areas is only $33.1 \%$ however, indicating that there is some difference in faunal composition between the two areas. However, due to the low number of stations used, these results are inconclusive and further testing is needed.

Commercial fisheries are important on the Northern Gulf of Mexico shelf, and comprise 20\% of the value of all US landings (NMFS, 1996). The largest volume fishery is for Gulf Menhaden (Brevoortia patronus), and stocks are fully utilized. This species is low in the food chain, and although the catch is large in volume it is low in value and produces mainly fish meal, oil, and soluble proteins (NMFS, 1996). The Atlantic croaker (Micropogonias undulatus) is another important but low value species; the stock is overfished, and is now most often taken as by-catch in other fisheries (Dagg et al., 2000). The highest value fishery in the Gulf of Mexico is the shrimp fishery, which has been pursued commercially on the shelf since the late-1800s. The fishery takes many non-target species such as red snappers (Lutjanus campechanus), croakers, and sea trout (Cynoscion spp) as by-catch. In one year, approximately 7.5 billion Atlantic croaker were caught and discarded by shrimp trawlers (NMFS, 1996). The by-catch is juveniles and the shrimp fishery is a major source of mortality for the species involved.

So it would seem, like shelf fisheries everywhere, that those in the Gulf of Mexico will find themselves in trouble. As traditionally harvested fish species have declined in polar and temperate seas, there has been a shift from the shelves towards exploitation of deepsea fish on the slopes (Moore, 1999). In Newfoundland, the fishery for cod closed in 1992 and there was an attempted compensation by building a fishery for the deep-sea Greenland halibut (Hopper, 1995; Murawski et al., 1997). There have also been similar attempts to establish slope fisheries for deepsea species such as grenadiers (Macrouridae), oreos (Oreosomatidae) and others in various parts of the world (Koslow et al., 2000).

Ours is the first study that has analyzed the deepsea demersal fish fauna in the Gulf of Mexico. An important finding is that none of the dominant fish are now commercial species, nor are they likely to be; however they may be taken as by-catch. Unlike slope species in more northerly, cool-water areas, the deepsea fish in the Gulf of Mexico are small, apparently not particularly schooling, and quite low in abundance. Furthermore, there is no market demand for these unfamiliar species (Hopper, 1995; Moore and Mace, 1999). As a result, deep-sea fish in the Gulf of Mexico do not have the attributes that make for viable fisheries and are not likely to be directly targeted for future harvesting.

\section{Conclusion}

Fish assemblages sampled in May and June in the Gulf of Mexico are zoned with depth. Species richness is highest on the upper slope and decreases with increasing depth. Fauna in the Gulf do not show an east-to-west gradient, but richness and diversity are higher in the east and west than in the central transect. At shallow depths, fish abundance was found to be higher in the Mississippi Trough than in other areas. No difference was found between fishes caught in and out of basins, but the data are inconclusive due to the limited number of samples. Therefore, more samples need to be taken in and out of basins at similar depths to make any conclusions between the fauna in these 
regions in the Gulf of Mexico. The fish assemblages in the deep zone do not appear to contain species with any commercial potential.

\section{Acknowledgements}

This research was funded by the Minerals Management Service through contract No. 1435-0199-CT-30991 as part of the Deepwater Program: Northern Gulf of Mexico Continental Slope Habitats and Benthic Ecoloyg (DGoMB).

\section{References}

ANDERSON, M. E., R. E. CRABTREE, H. J. CARTER, K. J. SULAK, and M. D. RICHARDSON. 1985. Distribution of demersal fishes of the Caribbean Sea found below 2000 metres. Bull. Mar. Sci., 37: 794-807.

BERGSTAD, O. A. 1990. Ecology of the fishes of the Norwegian Deep: distribution and species assemblages. Neth. J. Sea Res., 25: 237-266.

BERGSTAD, O. A., O. BJELLAND, and J. D. M. GORDON. 1999. Fish communities on the slope of the eastern Norwegian Sea. Sarsia, 84: 67-68.

BIANCHI, G. 1991. Demersal assemblages of the continental shelf and slope edge between the Gulf of Tehuantepec (Mexico) and the Gulf of Papagayo. Mar. Ecol. Prog. Ser., 73: 121-140.

1992. Study of the demersal assemblages of the continental shelf and upper slope off Congo and Gabon, based on the trawl surveys of the RV "Dr. Fridtjof Nansen". Mar. Ecol. Prog. Ser., 85: 9-23.

CARTES, J. E., and F. SARDA. 1993. Zonation of deep-sea decapod fauna in the Catalan Sea (western Mediterranean). Mar. Ecol. Prog. Ser. 94: 27-34.

CONNELL, S. D. and M. P. LINCOLN-SMITH. 1999. Depth and the structure of assemblages of demersal fish: experimental trawling along a temperate coast. Estuar. Coast. Shelf Sci., 48: 483-495.

DAGG, M., P. ORTNER, and J. TORRES. 2000. GLOBEC in the Gulf of Mexico: Large rivers and marine populations. Report of a U.S. GLOBEC Workshop, 1999. Global Change Research Program, Report 19, 31 p.

FARINA, A. C., J. FREIRE, and E. GONZALEZGURRIRAN. 1997. Demersal Fish Assemblages in the Galician continental shelf and upper slope (NW Spain): spatial structure and long-term changes. Estuar. Coast. Shelf Sci., 44: 435-454.

FUJITA, T., T. INADA, and Y. ISHITO. 1995. Depth gradient structure of the demersal fish community on the continental shelf and upper slope off Sendai Bay, Japan. Mar. Ecol. Prog. Ser., 118: 13-23.

GAGE, J. D. and P. A. TYLER. 1991. Deep-Sea Biology: A Natural History of Organisms at the Deep-Sea Floor. Cambridge University Press, Cambridge, 504 p.

GOMES, M. C., R. L. HAEDRICH, and J. C. RICE. 1992. Biogeography of groundfish assemblages on the Grand Bank. J. Northw. Atl. Fish Sci., 14: 13-27.
GORDON, J. D. M., N. R. MERRETT, and R. L. HAEDRICH. 1995. Environmental and biological aspects of slope-dwelling fishes. In: Deep Water Fisheries of the North Atlantic Oceanic Slope, A.G. Hopper (ed.), Kluwer Academic Publishers, Dordrecht, p. 1-30.

HAEDRICH, R. L., and N. R. MERRETT. 1988. Summary atlas of deep-living demersal fishes in the North Atlantic Basin. J. Nat. Hist., 22: 1325-1362.

HAEDRICH, R. L., and G. KREFFT. 1978. Distribution of bottom fishes in the Denmark Strait and Irminger Sea. Deep Sea Res., 25: 705-720.

HAEDRICH. 1997. Distribution and population ecology. In: Deep-Sea Fishes. D. J. Randall and A. P. Farrell (eds.). Academic Press, San Diego, California, p. 79-114.

HECKER, B. 1990. Variation in megafaunal assemblages on the continental margin south of New England. Deep Sea Res., 37: 37-57.

1994. Unusual megafaunal assemblages on the continental slope off Cape Hatteras. Deep-Sea Res. II. 41: 809-834.

HOPPER, A. G. (Ed.). 1995. Deepwater Fisheries of the North Atlantic Oceanic Slope. Kluwer Academic Publishers Group, Norwell, Massachusetts, 420 p.

JACOB, W., S. MCCLATCHIE, P. K. PROBERT, and P. J. HURST. 1998. Demersal fish assemblages off Southern New Zealand in relation to depth and temperature. Deep Sea Res., 45: 2119-2155.

KOSLOW, J. A., G. W. BOEHLERT, J. D. M. GORDON, R. L. HAEDRICH, P. LORANCE, and N. PARIN. 2000. Continental slope and deep-sea fisheries: implications for a fragile ecosystem. ICES J. Mar. Sci., 57: 548-557.

KREBS, C. J. 1994. Ecology, The Experimental Analysis of Distribution and Abundance, $4^{\text {th }}$ ed. HarperCollins College Publishers, New York, New York, 801 p.

KREBS, C. J. 1999. Ecological Methodology, $2^{\text {nd }}$ ed. AddisonWesley Educational Publishers, Menlo Park, California. $620 \mathrm{p}$.

MCClATCHIE, S., R. B. Millar, F. WEBSter, P. J. LESTER, R. HURST, and N. BAGLEY. 1997. Demersal fish community diversity off New Zealand: is it related to depth, latitude and regional surface phytoplankton? Deep Sea Res., 44(4): 647-667.

MCEACHRAN, John D., and Janice D. FECHHELM. 1998. Fishes of the Gulf of Mexico Vol. I. University of Texas Press, Austin, Texas, $1112 \mathrm{p}$.

MEFFE, G. K., and C. R. CARROLL. 1997. Principles of Conservation Biology, $2^{\text {nd }}$ ed. Sinauer Associates, Inc., Sunderland, Massachusetts, 729 pages.

MERRETT, N. R., and R. L. HAEDRICH. 1997. Deep-Sea Demersal Fish and Fisheries. Chapman and Hall, London, UK, 282 p.

MERRETT, N. R., J. D. M. GORDON, M. STEHMANN, and R. L. HAEDRICH. 1991. Deep demersal fish assemblage structure in the Porcupine Seabight (eastern North Atlantic): slope sampling by three different trawls compared. J. Mar. Biol. Assoc. U. K., 71:329-358.

MOORE, J. A. 1999. Deep-sea finfish fisheries: lessons from history. Fisheries, 24: 16-21.

MOORE, J. A. and P. M. MACE. 1999. Challenges and 
prospects for deep-sea finfish fisheries. Fisheries, 24: 22-23.

MORANTA, J., C. STEFANESCU, E. MASSUTI, B. MORALES-NIN and D. LLORIS. 1998. Fish community structure and depth related trends on the continental slopes of the Balearic Islands (Algerian Basin, western Mediterranean). Mar. Ecol. Prog. Ser., 171: 247-259.

MURAWSKI, S. A., J. J. MAGUIRE, R. K. MAYO, and F. M. SERCHUK. 1997. Groundfish stocks and the fishing industry. In: Northwest Atlantic Groundfish: Perspectives on a Fishery Collapse. J. Boreman, B.S. Nakashima, J.A. Wilson, and R.L. Kendell (eds.). American Fisheries Society, Bethesda, Maryland, p. 27-70.

NMFS. 1996. Our Living Oceans. Report on the status of U.S. living marine resources, 1995. U.S. Dep. Comm., NOAA Tech. Memo, NMFS-F/SPO-19, 160 p.

OMORI, M. and T. IKEDA. 1984. Methods in Marine Zooplankton Ecology. Wiley-Interscience, John Wiley \& Sons, New York. 332 p.

PEQUEGNAT, W. E., B. J. GALLAWAY, and L. H. PEQUEGNAT. 1990. Aspects of the ecology of the deepwater fauna of the Gulf of Mexico. Amer. Zool. 30: 45-64.

POWELL, S. M. MS 2001. Analysis of the fish fauna of the deep northern Gulf of Mexico. MES thesis report, Memorial University of Newfoundland, August 2001, $53 \mathrm{p}$.

ROWE, G. T. and M. C. KENNICUTT II (eds.). 2000. Deepwater Program: Northern Gulf of Mexico Continental Slope Habitat and Benthic Ecology. Year I Interim Report. OCS Study MMS 2001-00. U.S. Department of the Interior, Minerals Management Service, Gulf of Mexico OCS Region, New Orleans, Louisiana.

SALVADOR, A. (ed). 1991. The Gulf of Mexico Basin. The Geological Society of America, Inc., Boulder, Colorado. $568 \mathrm{p}$.

SCOTT, W. B. and M. G. SCOTT. 1988. Atlantic Fishes of Canada. Can. Bull. Fish. Aquat. Sci., 219: 731 p.

STEFANESCU, C., D. LLORIS, and J. RUCABADO. 1993. Deep-sea fish assemblages in the Catalan Sea (western Mediterranean) below a depth of 1000 m. Deep-Sea Res., 40: 695-707. 
Appendix Table 1. Stations and species included in the four faunal assemblages identified in this study. Entries are numbers of individuals in each species.

Stations:

Shelf: $\quad$ S44, RW1

Upper slope: C1, MT1, S42, S43, W1, W2

Mid-slope: $\quad$ C4, C7, MT2, MT3, MT4, S35, W3, WC5

Deep: $\quad$ B1, B2, B3, C12, MT5, MT6, NB2, NB3, NB5, S36, S37, S38, S40, S41, W6

\begin{tabular}{|c|c|c|c|c|}
\hline \multirow[b]{2}{*}{ Species } & \multirow[b]{2}{*}{ Shelf } & \multicolumn{2}{|c|}{ Fish Assemblages } & \multirow[b]{2}{*}{ Deep } \\
\hline & & Upper Slope & Mid-slope & \\
\hline Acanthonus armatus & - & - & - & 9 \\
\hline Aldrovandia affinis & - & - & - & 3 \\
\hline Aldrovandia gracilis & - & - & - & 4 \\
\hline Alepocephalid & - & - & - & 1 \\
\hline Alepocephalus agassizii & - & - & - & 1 \\
\hline Alepocephalus productus & - & - & - & 3 \\
\hline Ancylopsetta dilecta & 2 & - & - & - \\
\hline Antigonia capros & 34 & - & - & - \\
\hline Apristurus laurussonii & - & - & 2 & - \\
\hline Argentina striata & - & 1 & - & - \\
\hline Barathrites sp. & - & - & - & 1 \\
\hline Barathrodemus manatinus & - & - & - & 1 \\
\hline Bassogigas gillii & - & - & - & 1 \\
\hline Bassozetus robustus & - & - & - & 10 \\
\hline Bassozetus sp. & - & - & - & 1 \\
\hline Bathygadus macrops & - & 22 & 34 & - \\
\hline Bathygadus melanobranchus & - & - & 16 & - \\
\hline Bathyonus pectoralis & - & - & - & 4 \\
\hline Bathypterois grallator & - & - & - & 3 \\
\hline Bathypterois phanex & - & - & - & 1 \\
\hline Bathysaurus mollis & - & - & - & 4 \\
\hline Bathytroctes microlepis & - & - & 1 & - \\
\hline Bathytyphlops sewelli & - & - & - & 1 \\
\hline Bellocia koefoedi & - & - & - & 1 \\
\hline Bembrops anatirostris & 3 & - & - & - \\
\hline Bembrops gobioides & - & 31 & - & - \\
\hline Benthodesmus tenuis & - & 3 & 2 & - \\
\hline Caelorinchus caelorhinchus & - & 24 & - & - \\
\hline Caelorinchus caribbaeus & - & 53 & - & - \\
\hline Caelorinchus occa & - & - & 1 & - \\
\hline Caelorinchus sp. & - & - & 1 & - \\
\hline Cetonurus globiceps & - & - & 25 & - \\
\hline Chaunax suttkusi & - & - & 9 & - \\
\hline Chlorophthalmus agassizi & - & 27 & - & - \\
\hline Citharichthys cornutus & 1 & - & - & - \\
\hline Coloconger meadi & - & 1 & 1 & - \\
\hline Conocara macroptera & - & - & 3 & - \\
\hline Coryphaenoides alateralis & - & - & 1 & - \\
\hline Coryphaenoides mediterraneus & - & 3 & - & 9 \\
\hline Coryphaenoides mexicanus & - & - & 13 & - \\
\hline Coryphaenoides rudis & - & - & - & 2 \\
\hline Coryphaenoides zaniophorus & - & 1 & 61 & - \\
\hline Cyttopsis roseus & - & 4 & - & - \\
\hline Dibranchus atlanticus & - & 29 & 4 & 2 \\
\hline Dicrolene intronigra & - & 6 & 31 & 4 \\
\hline
\end{tabular}


Appendix Table 1. (Continued). Stations and species included in the four faunal assemblages identified in this study. Entries are numbers of individuals in each species.

\section{Stations:}

Shelf: $\quad$ S44, RW 1

Upper slope: C1, MT1, S42, S43, W1, W2

Mid-slope: C4, C7, MT2, MT3, MT4, S35, W3, WC5

Deep: $\quad$ B1, B2, B3, C12, MT5, MT6, NB2, NB3, NB5, S36, S37, S38, S40, S41, W6

\begin{tabular}{|c|c|c|c|c|}
\hline \multirow[b]{2}{*}{ Species } & \multicolumn{4}{|c|}{ Fish Assemblages } \\
\hline & Shelf & Upper Slope & Mid-slope & Deep \\
\hline Dicrolene kanazawai & - & - & - & 12 \\
\hline Diplacanthopoma brachysoma & - & - & 1 & - \\
\hline Epigonus pandionis & - & 6 & - & - \\
\hline Etmopterus schultzi & - & 9 & 13 & - \\
\hline Fenestraja sinusmexicanus & - & 2 & 7 & 1 \\
\hline Gadella imberbis & - & 2 & - & - \\
\hline Gadomus arcuatus & - & - & 4 & - \\
\hline Gadomus longifilus & - & - & 14 & - \\
\hline Gadomus macrops & - & 2 & - & - \\
\hline Gadomus sp. & - & - & 2 & - \\
\hline Gibberichthys pumilus & - & - & 1 & - \\
\hline Halosaurus guentheri & - & - & 1 & - \\
\hline Halosaurus ovenii & - & 1 & 1 & - \\
\hline Hoplostethus occidentalis & - & 5 & - & - \\
\hline Hydrolagus alberti & - & - & 5 & - \\
\hline Hydrolagus mirabilis & - & - & 2 & - \\
\hline Hymenocephalus billsamorum & - & 15 & - & - \\
\hline Ipnops murrayi & - & - & - & 4 \\
\hline Kali indica & - & - & 1 & - \\
\hline Laemonema goodebeanorum & - & 29 & - & - \\
\hline Laemonema sp. & - & 2 & - & - \\
\hline Lepophidium brevibarbe & 3 & - & - & - \\
\hline Leptoderma macrops & - & - & 1 & - \\
\hline Lophius gastrophysus & - & 1 & - & - \\
\hline Luciobrotula corethromycter & - & - & - & 2 \\
\hline Macrouridae & - & 2 & - & - \\
\hline Malacocephalus laevis & - & 2 & - & - \\
\hline Malacocephalus occidentalis & - & 1 & - & - \\
\hline Merluccius albidus & - & 6 & 10 & - \\
\hline Monolene sessilicauda & 2 & - & - & - \\
\hline Monomitopus agassizii & - & 3 & 9 & - \\
\hline Narcetes stomias & - & - & - & 5 \\
\hline Nezumia aequalis & - & 8 & 49 & - \\
\hline Nezumia cyrano & - & 1 & 70 & - \\
\hline Nezumia suilla & - & - & 4 & - \\
\hline Paralichthys squamilentus & 1 & - & - & - \\
\hline Parasudis truculenta & - & 10 & - & - \\
\hline Penopus macdonaldi & - & - & 2 & - \\
\hline Peristedion greyae & - & 6 & - & - \\
\hline Peristedion miniatum & 10 & 1 & - & - \\
\hline Poecilopsetta beani & - & 4 & - & - \\
\hline Polymixia lowei & - & 3 & - & - \\
\hline Pontinus longispinis & 1 & 18 & - & - \\
\hline Porogadus catena & - & - & - & 3 \\
\hline
\end{tabular}


Appendix Table 1. (Continued). Stations and species included in the four faunal assemblages identified in this study. Entries are numbers of individuals in each species.

Stations:

Shelf: $\quad$ S44, RW1

Upper slope: C1, MT1, S42, S43, W1, W2

Mid-slope: $\quad$ C4, C7, MT2, MT3, MT4, S35, W3, WC5

Deep: $\quad$ B1, B2, B3, C12, MT5, MT6, NB2, NB3, NB5, S36, S37, S38, S40, S41, W6

\begin{tabular}{|c|c|c|c|c|}
\hline \multirow[b]{2}{*}{ Species } & \multicolumn{4}{|c|}{ Fish Assemblages } \\
\hline & Shelf & Upper Slope & Mid-slope & Deep \\
\hline Porogadus miles & - & - & - & 3 \\
\hline Pristipomoides aquilonaris & 1 & - & - & - \\
\hline Rajella fuliginea & - & - & 1 & - \\
\hline Rajella purpurventralis & - & - & 1 & - \\
\hline Rhinochimaera atlantica & - & - & 1 & - \\
\hline Rouleina maderensis & - & - & - & 1 \\
\hline Saurida normani & 2 & - & - & - \\
\hline Scombrolabrax heterolepis & - & - & 1 & - \\
\hline Scyliorhinus retifer & - & 1 & - & - \\
\hline Setarches guentheri & - & 4 & - & - \\
\hline Squalogadus modificatus & - & - & 15 & - \\
\hline Squatina dumeril & 1 & - & - & - \\
\hline Steindachneria argentea & - & 38 & - & - \\
\hline Synagrops bellus & - & 4 & - & - \\
\hline Synagrops spinosus & 1 & - & - & - \\
\hline Synaphobranchus affinis & - & - & - & 1 \\
\hline Synaphobranchus oregoni & - & 2 & 6 & - \\
\hline Talismania antillarum & - & - & 2 & - \\
\hline Thaumatichthys plagiostomus & - & - & - & 1 \\
\hline Trachichthyid & - & - & 1 & - \\
\hline Trachonurus sulcatus & - & 1 & - & - \\
\hline Trichiurus lepturus & - & - & 2 & - \\
\hline Trichopsetta ventralis & 1 & - & - & - \\
\hline Urophycis cirrata & 1 & 21 & - & - \\
\hline Ventrifossa macropogon & - & 3 & - & - \\
\hline Xyelacyba myersi & - & - & - & 2 \\
\hline Yarrella blackfordi & - & 36 & 9 & - \\
\hline Zalieutes mcgintyi & 2 & - & - & - \\
\hline Zenopsis conchifera & - & 2 & - & - \\
\hline
\end{tabular}


